\title{
Penggunaan Buku Ajar Cosmopolite 1 untuk Pembelajaran Français Langue Étrangère
}

\author{
Evaluation of The Use of The Cosmopolite 1 Teaching Book for Français Langue \\ Étrangère Learning
}

\author{
Tania Intan ${ }^{1, *}$, Vincentia Tri Handayani ${ }^{2}$, dan Ferli Hasanah ${ }^{3}$ \\ ${ }^{1,2,3}$ Universitas Padjadjaran \\ J1. Raya Bandung Sumedang, KM 21, Jatinangor, Sumedang, Indonesia

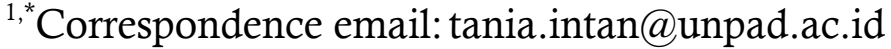 \\ 2Email: v.tri@unpad.ac.id \\ ${ }^{3}$ Email: ferli.hasanah@unpad.ac.id
}

Received: 16 Juni 2020 Revised: 4 Agustus 2020 Accepted: 7 Oktober 2020

\begin{abstract}
Textbooks have a very important function in education because they facilitate the teaching and learning process for teachers and learners. Teaching material is considered good if it contains educational content that facilitates learners learning actively and independently. This research was conducted to evaluate the use of Cosmopolite 1 textbooks in learning French in the French Literature Study Program at Padjadjaran University. The study was conducted using a combination of quantitative and qualitative methods, and data were collected in January 2020 through filling out questionnaires and literature studies, for later review descriptively. The lecturer respondents consisted of three people who supported Basic French, while the student respondents consisted of thirty people who were chosen based on the lecturers' recommendations. The evaluation results showed that the Cosmopolite 1 was rated positively by the lecturer and student respondents. Besides, the book fulfils the criteria of selfinstructional, self-contained, stand-alone, adaptive, and user friendly. The recommendation made from this research is that an evaluation should always be carried out on all elements of learning, including textbooks.
\end{abstract}

Keywords: evaluation, textbooks, Cosmopolite 1, French learning

Abstrak: Buku ajar memiliki fungsi yang sangat penting dalam pendidikan karena memudahkan proses belajar mengajar bagi pengajar dan pembelajar. Bahan ajar dianggap baik jika mengandung isi pendidikan yang memudahkan pembelajar belajar secara aktif dan mandiri. Penelitian ini dilakukan untuk mengevaluasi penggunaan buku ajar Cosmopolite 1 dalam pembelajaran bahasa Perancis di Program Studi Sastra Perancis Universitas Padjadjaran. Penelitian dilakukan dengan metode kombinasi kuantitatif dan kualitatif, dan data dikumpulkan pada bulan Januari 2020 melalui pengisian kuesioner dan studi pustaka, untuk kemudian dikaji secara deskriptif. Responden dosen terdiri atas tiga orang pengampu mata kuliah Bahasa Perancis Dasar, sedangkan responden mahasiswa terdiri dari tiga puluh orang yang dipilih berdasarkan rekomendasi para dosen. Hasil evaluasi menunjukkan bahwa Cosmopolite 1 dinilai positif oleh responden dosen dan mahasiswa. Selain itu, buku tersebut memenuhi kriteria selfinstructional, selfcontained, stand alone, adaptive, dan user friendly. Rekomendasi yang diajukan dari penelitian ini adalah agar evaluasi senantiasa dilakukan terhadap seluruh elemen pembelajaran, termasuk buku ajar.

Kata kunci: evaluasi, buku ajar, Cosmopolite 1, pembelajaran bahasa Perancis

To cite this article:

Intan, T., Handayani, V. T., \& Hasanah, F. (2021). Penggunaan Buku Ajar Cosmopolite 1 untuk Pembelajaran Français Langue Étrangère. Diglosia: Jurnal Kajian Bahasa, Sastra, dan Pengajarannya, 4(1), 1-12. https://doi.org/10.30872/diglosia.v4i1.82 


\section{A. PENDAHULUAN}

Pembelajaran bahasa Perancis sebagai bahasa asing atau FLE (Français Langue Etrangère) membutuhkan buku ajar yang mengacu pada CECR (Cadre Européen Commun de Référence Pour des Langues). CECR adalah dokumen resmi Dewan Uni Eropa yang memuat kerangka acuan kebahasaan yang mencakup pembelajaran, pengajaran, dan pengukuran. Kerangka acuan ini berisi seperangkat sistem untuk mengatur standar keberhasilan yang dicapai dalam tahapan pembelajaran dalam konteks internasional (Mahriyuni, 2016, hal. 1). CECR diresmikan pada tahun 2001 dan berlaku dalam pembelajaran bahasa Perancis di seluruh dunia dengan tingkatan kompetensi yang disebut DELF (A1, A2, B1, B2) dan DALF (C1, C2) (Mulyadi, 2014, hal. 48). Pembelajaran bahasa Perancis dalam hal ini menurut Sumiyati dan Surjono (2014, hal. 200) dilakukan dengan pendekatan komunikatif yang lebih menekankan pada pemerolehan kompetensi komunikatif.

Bahasa, menurut Ellis (2005) dan Hornberger \& McKay (2010) yang dikutip oleh Cahyani \& Hadiyanto (2018, hal. 119), diperoleh manusia melalui proses pembelajaran baik secara alamiah maupun nonalamiah/dikondisikan. Untuk mencapai pembelajaran bahasa yang efektif, selain guru harus membantu siswa membangun pengetahuannya, keberadaan media pembelajaran atau buku ajar yang sesuai dengan target kompetensi dan situasi sosial budaya pembelajar pun diperlukan) (Adawiyah, 2016). Baskoro (2008) memaparkan dalam Halijah, Susilo, \& Mulawarman (2020, hal. 117-118) bahwa media pembelajaran adalah segala sesuatu yang dapat digunakan untuk menyalurkan pesan yang dapat merangsang pikiran, perasaan, perhatian, dan kemauan seseorang sehingga dapat mendorong terjadinya proses belajar mengajar sesuai dengan tujuan yang telah ditetapkan.

Meskipun buku ajar ditujukan kepada siswa/mahasiswa, guru/dosen pun terbantu karena guru dapat memper-timbangkan apa yang akan disampaikan [ataupun tidak] kepada siswa. Guru memiliki kebebasan dalam memilih, mengembangkan, dan menyajikan materi karena setiap aktivitas tersebut merupakan wewenang dan kewajiban profesionalnya (Suryaman, 2006, hal. 167).

Program Studi Sastra Perancis Universitas Padjadjaran telah menggunakan Cosmopolite 1 sejak tahun 2017 untuk menggantikan Alter Ego 1 sebagai dijadikan buku ajar untuk mata kuliah Bahasa Perancis Awal selama lima tahun. Cosmopolite 1 adalah sebuah méthode de français untuk pembelajar bahasa Perancis pemula yang disusun oleh Nathalie Hirschprung dan Tony Tricot, yang diterbitkan oleh Hachette Français Langue Etrangère pada tahun 2017. Buku ini terdiri dari 224 halaman yang terbagi menjadi delapan dossiers 'bab'. Media pendukung yang disediakan sebagai pendamping buku ini adalah sebuah DVD ROM dan sebuah cahier d'activités 'buku latihan'. Kelebihan lain dari buku ini adalah kualitas tata letak dan gambar yang baik (Intan, Wardiani, \& Hasanah, 2019). Menurut para penyusunnya, buku Cosmopolite 1 engage l'étudiant dans un apprentissage innovant de la langue et de la culture françaises à travers des situations réelles et partagées par des Français, des francophones et des francophiles partout dans le monde "membawa siswa dalam pembelajaran inovatif dari bahasa dan budaya Perancis melalui situasi nyata yang dialami oleh orang Perancis, frankofon, dan para pencinta bahasa Perancis di seluruh dunia (Tim Hachette FLE, 2016).

Meskipun telah dinilai memiliki kualitas dan kelengkapan yang baik (Intan, Wardiani, \& Hasanah, 2019), buku ajar Cosmopolite 1 yang telah digunakan dalam dua tahun akademik ini perlu dievaluasi efektivitasnya. Dengan adanya evaluasi 
terhadap bahan ajar, akan diketahui kualitas bahan ajar tersebut dan kemudian akan diambil keputusan apakah akan tetap digunakan atau diganti dengan bahan ajar yang lebih baik. Langkah lain yang dapat ditempuh adalah memodifikasi, menambah, atau mengurangi materi yang tersedia di dalam buku tersebut. Evaluasi penggunaan bahan ajar Cosmopolite 1 perlu dilakukan untuk mengetahui kualitas bahan tersebut dan memeriksa kesiapan bahan ajar tersebut untuk digunakan oleh mahasiswa secara mandiri.

Belajar secara mandiri memang menjadi wacana yang semakin dimunculkan karena adanya perbedaan kemampuan belajar dan gaya belajar peserta didik dalam mempelajari bahasa Perancis. Jumlah peserta didik dalam satu kelas yang tidak ideal untuk pelajaran bahasa juga, menurut (Sari, 2017, hal. 216), turut memengaruhi. Untuk mengatasi situasi itulah, evaluasi terhadap kelas perlu dilakukan, selain untuk memverifikasi efektivitas penggunaannya di kelas, juga untuk menarik minat mahasiswa belajar di luar jam pelajaran.

Istilah buku ajar sering kali disamakan dengan buku teks atau buku pelajaran. Tarigan (1986, hal. 13) menyebutkan bahwa buku jenis ini disusun oleh para pakar dalam bidang tertentu untuk tujuan instruksional yang dilengkapi dengan saranasarana pengajaran yang serasi dan mudah dipahami oleh para pemakainya di sekolah dan perguruan tinggi sehingga dapat menunjang suatu program pengajaran. Pujiati (2007, hal. 38) menjelaskan bahwa bahan ajar merupakan seperangkat teaching material 'materi atau substansi pelajaran' yang disusun secara sistematis, untuk menampilkan sosok utuh dari kompetensi yang akan dikuasai siswa dalam kegiatan pembelajaran. Bahan ajar memungkinkan siswa mempelajari suatu kompetensi atau sub kompetensi secara runtut dan sistematis sehingga secara akumulatif mampu menguasai semua kompetensi secara utuh dan terpadu. Menurut Hernawan (2010, hal. 1), bahan ajar harus dikaji, dicermati, dipelajari, dan dijadikan materi yang akan dikuasai [maha]siswa dan sekaligus memberikan pedoman untuk mempelajarinya. Sebagai bahan ajar, buku ajar harus memiliki beberapa karakteristik, yaitu: self instructional, self contained, stand alone, adaptive, dan user friendly.

Buku ajar memiliki fungsi yang sangat penting dalam bidang pendidikan karena akan memudahkan proses belajar mengajar bagi pengajar dan pembelajar. Bagi pengajar, buku ajar menjadi buku pedoman sebagai sumber materi pengajaran. Sedangkan bagi pembelajar, buku teks dapat membantu, merangsang, dan menunjang aktivitas pembelajar (Mutiarsih, 2005). Majid (2007) menambahkan bahwa buku ajar disusun dengan empat tujuan, yaitu: membantu siswa dalam mempelajari sesuatu, menyediakan berbagai jenis pilihan bahan ajar, memudahkan dirinya dalam melaksanakan pembelajaran, dan agar kegiatan pembelajaran menjadi menarik.

Menurut Suparman (2013) yang dikutip Dhewi \& Hadiwidjaja (2014, hal. 5), bahan ajar yang baik mengandung isi pendidikan dengan teori pedagogi yang memudahkan pembelajar belajar secara aktif mandiri. Bahan pembelajaran dapat berperan sebagai bahan belajar mandiri, apabila telah didesain secara lengkap. Bahan pembelajaran ini dilengkapi dengan tujuan pembelajaran atau kompetensi yang akan dicapai. Materi pembelajaran diuraikan dalam kegiatan belajar, ilustrasi media, prosedur pembelajaran, latihan yang harus dikerjakan dilengkapi rambu jawaban, tes formatif dilengkapi dengan kunci jawaban, umpan balik, daftar pustaka. Komplemen yang dapat disertakan, misalnya: modul pembelajaran, audio pembelajaran, video/ CD pembelajaran, dan CAI (Hernawan et al., 2010). 
Dalam sebuah bahan ajar, baik buku, modul, atau pun materi lainnya, prinsip keterbacaan merupakan hal yang paling mendasar. Sebagaimana dikutip Dhewi \& Hadiwidjaja (Dhewi \& Hadiwidjaja, 2014), Klare (1963) mendefinisikan karakter 'mudah dibaca' sebagai "kemudahan pemahaman karena gaya penulisannya, di luar konten dan pengorganisasian." Sedangkan menurut Mc Laughlin (1969) yang dikutip Fatin (2017), keterbacaan adalah "anggapan suatu kelas bahwa materi tersebut menarik dan mudah dipahami." Dengan demikian, sebuah bahan ajar yang baik harus dapat dimengerti dengan mudah oleh pembacanya melalui alur penulisan yang sistematis, tidak ada kesalahan tanda baca, dan dapat menimbulkan ketertarikan pembaca untuk semakin memahami materi yang terkandung di dalamnya. Rahman, Sahlan, \& Badara (2020, hal. 9) juga berargumentasi bahwa suatu buku ajar dianggap baik dan layak digunakan jika telah memiliki teknik penyajian, pendukung penyajian, serta koherensi dan keruntutan alur berpikir yang baik.

Penelitian terdahulu mengenai penelaahan buku ajar bidang kebahasaan telah dilakukan misalnya oleh Hijriah (2017) yang meneliti Evaluasi Buku Ajar Bahasa Arab: Telaah terhadap Instrumen Penilaian Badan Standar Nasional Pendidikan (BSNP) dan Rusydi Ahmad Thu'aimah. Kajian tersebut menggunakan instrumen penilaian buku yang ditetapkan BSNP (2007), bahwa buku teks yang berkualitas wajib memenuhi empat unsur kelayakan, yaitu kelayakan isi/ materi, kelayakan penyajian, kelayakan kebahasaan, dan kelayakan secara grafis.

Pembahasan tentang buku ajar juga dilakukan Mayasari, Sapri, \& Turdja'i (2019) yang mengkaji Pengembangan Bahan Ajar Bahasa Jerman Berbasis Komik untuk Meningkatkan Kosakata dan Keterampilan Berbicara, sedangkan Rahman, Sahlan, \& Badara (Rahman, Sahlan, \& Badara, 2020) membahas Evaluasi Bahan Ajar Bahasa dan Sastra Indonesia. Analisis terhadap buku-buku ajar bahasa Perancis juga telah dipraktikkan pada Campus (Mutiarsih, 2005), Complete French 1 (Oktari, 2013), Alter Ego (Shafwatun, 2016), Café Crème, Campus, dan Echo (Utami, 2016) dan Le Mag (Sari, 2018).

Penelitian ini dapat dianggap sebagai kelanjutan dari kajian sebelumnya terhadap buku ajar Cosmopolite 1 (Intan, Wardiani, \& Hasanah, 2019) yang dibatasi pada aspek ideologi gender dan kelayakannya sebagai sebuah materi pengajaran bahasa Perancis. Buku ajar tersebut dinilai memiliki kelebihan pada elemen-elemen berikut: (1) kondisi material (judul, pengarang, penerbit, jumlah halaman, penghargaan, dan format), (2) media pelengkap (buku latihan, media audio, media video, DVD ROM, buku pegangan pembelajar), (3) isi (pembagian bab dan subbab, pergerakan materi), dan (4) metode (pendekatan kebahasaan, jenis-jenis teks, integrasi aspek budaya, dan bagian lampiran). Sedangkan yang menjadi kelemahan dari buku ajar ini di antaranya adalah (1) pengantar buku ajar (petunjuk tentang publik sasaran kurang lengkap), (2) aktivitas dengan internet (jumlah situs yang diakses tidak diketahui), dan (3) kaitan dengan kurikulum (tujuan profesional tidak disebutkan).

Dengan latar belakang yang telah dipaparkan ini, maka tujuan penelitian ini dapat diidentifikasi sebagai berikut: (1) mempelajari efektivitas penggunaan buku ajar Cosmopolite 1 dalam pembelajaran bahasa Perancis menurut pengajar dan pembelajar dan (2) mengembangkan buku ajar dapat dilakukan untuk meningkatkan kualitas pembelajaran bahasa Perancis. 


\section{B. METODE}

Objek untuk penelitian ini adalah dua jenis data, yaitu data primer dan sekunder. Data primer berupa hasil kuesioner tentang evaluasi penggunaan buku ajar Cosmopolite 1 yang telah diisi oleh para responden, yang terdiri atas tiga orang dosen dan tiga puluh orang mahasiswa selama bulan Januari 2020. Ketiga orang dosen telah mengampu mata kuliah Bahasa Perancis Dasar sehingga telah menggunakan buku ajar tersebut di kelas masing-masing. Sedangkan para mahasiswa yang juga telah menggunakan buku tersebut dalam perkuliahan dipilih secara purposif oleh dosen. Data sekunder penelitian ini adalah buku Cosmopolite 1 (Hirschprung \& Tricot, 2017), serta hasil kajian yang relevan dari berbagai artikel ilmiah dan buku referensi.

Kepada tiga responden dosen pengampu mata kuliah Bahasa Perancis Dasar yang telah memiliki pengalaman menggunakan buku ajar Cosmopolite 1, diajukan sebuah angket yang diisi secara daring melalui Google Form. Angket tersebut terdiri dari sepuluh pertanyaan berkaitan dengan penilaian profesional mereka terhadap buku ajar yang dianalisis, tabel kuesioner berisi sepuluh kriteria bahan ajar yang diajukan oleh Dhewi \& Hadiwidjaja (Dhewi \& Hadiwidjaja, 2014), serta kolom rekomendasi.

Angket untuk dosen sebagai salah satu instrumen penelitian diapropriasi dan dimodifikasi dari kuesioner pakar pada penelitian Dhewi \& Hadiwidjaja (Dhewi \& Hadiwidjaja, 2014). Validasi data kemudian dilakukan dengan metode triangulasi. Setelah diklasifikasikan dan ditabulasi, data dikaji dengan metode analisis kuantitatif dan kualitatif (interpretasi dan deskripsi terhadap data). Hasil simpulan dari penilaian ini dibahas kembali di antara responden dan tim peneliti, untuk kemudian melaksanakan perbaikan yang diaplikasikan pada semester berikutnya.

Penilaian yang dimaksud dalam penelitian ini adalah evaluasi formatif, yaitu salah satu sub domain dalam definisi teknologi pembelajaran. Seels dalam Oktarini \& Gafur (2014, hal. 41) menjelaskan bahwa evaluasi formatif adalah proses mengumpulkan informasi yang memadai untuk kemudian menggunakan informasi tersebut sebagai basis bagi pengembangan lebih lanjut dari objek yang dievaluasi.

\section{PEMBAHASAN}

\section{Evaluasi Penggunaan Buku Ajar Cosmopolite 1 dalam Pembelajaran Bahasa Perancis menurut Dosen Pengampu}

Seluruh responden menyatakan pernah menggunakan buku ajar tersebut selama 1 hingga 3 semester (1). Sebanyak 66,7\% responden menyatakan bahwa dibandingkan dengan buku ajar sebelumnya, yaitu Alter Ego 1, Cosmopolite 1 lebih tematis, terstruktur, sangat detail, dan teratur (2). Seluruh responden menyatakan tidak ada kesulitan berarti selama mengajar dengan menggunakan buku tersebut (3). Meskipun Cosmopolite 1 dianggap lengkap, seluruh responden menyatakan harus melengkapi proses pengajaran dengan buku dan media lain, seperti buku tata bahasa dan video tentang budaya Perancis (4). Menurut 66,7\% responden, mahasiswa terlihat antusias dalam menggunakan buku ajar itu karena materi yang dipelajari disesuaikan dengan perkembangan teknologi informatika seperti media sosial (5). Mahasiswa juga cenderung mendapatkan nilai yang baik dalam mata kuliah Bahasa Perancis Dasar menurut 66,7\% responden (6). Seluruh responden menyepakati bahwa ada relasi di antara kualitas buku ajar dengan ketercapaian proses 
pembelajaran, yang terungkap melalui tercapainya tujuan pembelajaran dan terealisasinya kondisi mahasiswa belajar secara mandiri (7).

Dalam proses pembelajaran, $66,7 \%$ responden tidak menggunakan seluruh perlengkapan buku ajar Cosmopolite 1 (buku pegangan, buku panduan guru, buku latihan, CD, dan situs yang dianjurkan) karena keterbatasan waktu di kelas (8). Namun materi yang belum tersampaikan dapat dipelajari di rumah karena menurut $66,7 \%$ responden, format dan komposisi buku ajar Cosmopolite 1 memungkinkan mahasiswa belajar aktif dan mandiri (9). Secara umum, seluruh responden menyatakan Cosmopolite 1 memenuhi asas keterbacaan, yang berarti mudah dipahami dan dipelajari mahasiswa (10).

Pada bagian selanjutnya, responden dosen mengisi tabel kuesioner dengan hasil sebagaimana Tabel 1.

Tabel 1. Kuesioner Pakar tentang Materi pada Buku Ajar

\begin{tabular}{|c|c|c|c|c|}
\hline \multirow{2}{*}{ No } & \multirow{2}{*}{ Kriteria } & \multicolumn{3}{|c|}{ Tingkat Kesesuaian } \\
\hline & & Rendah & Sedang & Tinggi \\
\hline 1. & $\begin{array}{l}\text { Materi sesuai dengan perkembangan pemikiran/ praktis } \\
\text { dalam bidang ilmu yang relevan }\end{array}$ & & $33,3 \%$ & $66,7 \%$ \\
\hline 2. & $\begin{array}{l}\text { Materi menjelaskan suatu konsep atau prinsip dengan } \\
\text { tuntas }\end{array}$ & & $33,3 \%$ & $66,7 \%$ \\
\hline 3. & $\begin{array}{l}\text { Materi menyajikan metode atau paradigma berpikir yang } \\
\text { konsisten dan berimbang }\end{array}$ & $33,3 \%$ & & $66,7 \%$ \\
\hline 4. & Materi tersusun logis, teratur, dan koheren & $33,3 \%$ & & $66,7 \%$ \\
\hline 5. & $\begin{array}{l}\text { Tingkat kesulitan dan kedalaman materi sesuai dengan } \\
\text { jenjang program }\end{array}$ & & $66,7 \%$ & $33,3 \%$ \\
\hline 6. & $\begin{array}{l}\text { Materi membantu menganalisis keterkaitan antara } \\
\text { kenyataan dengan teori, atau di antara teori-teori yang } \\
\text { dibahas }\end{array}$ & & $66,7 \%$ & $33,3 \%$ \\
\hline 7. & Tugas dan tes relevan dengan materi & & $33,3 \%$ & $66,7 \%$ \\
\hline 8. & $\begin{array}{l}\text { Materi tidak mengandung kesalahan penyampaian } \\
\text { informasi. }\end{array}$ & & & $100 \%$ \\
\hline 9. & $\begin{array}{l}\text { Materi dilengkapi dengan bagan dan ilustrasi yang } \\
\text { menambah pemahaman mahasiswa }\end{array}$ & & $33,3 \%$ & $66,7 \%$ \\
\hline 10. & Materi sesuai dengan situasi sosial budaya & & & $100 \%$ \\
\hline
\end{tabular}

Sumber: Kuesioner Pakar (Dhewi \& Hadiwidjaja, 2014)

\section{Tabel 2. Media Pelengkap Buku Ajar Cosmopolite 1}

\begin{tabular}{|c|c|}
\hline Deskripsi Objektif & Penilaian \\
\hline Buku latihan & $\begin{array}{l}\text { Cahier d'activités terdiri dari } 127 \text { halaman, yang terbagi atas latihan } \\
\text { untuk bab 1-8, portofolio, dan latihan komprehensif untuk persiapan } \\
\text { uilan DELF A1. }\end{array}$ \\
\hline Media audio & $\begin{array}{l}\text { Untuk siswa/mahasiswa disediakan DVD ROM dengan konfigurasi } \\
\text { minimal MAC versi } 10.5 \text { dan Windows XP, yang berisi dokumen } \\
\text { audio. }\end{array}$ \\
\hline Media video & $\begin{array}{l}\text { Untuk siswa/mahasiswa disediakan DVD ROM dengan konfigurasi } \\
\text { minimal MAC versi } 10.5 \text { dan Windows XP, yang berisi delapan } \\
\text { dokumen video. }\end{array}$ \\
\hline CD/DVD & $\begin{array}{l}\text { Untuk siswa/mahasiswa disediakan DVD ROM dengan konfigurasi } \\
\text { minimal MAC versi } 10.5 \text { dan Windows XP, yang berisi dokumen } \\
\text { audio dan delapan dokumen video. }\end{array}$ \\
\hline Buku Pegangan Pengajar & $\begin{array}{l}\text { Guide pédagogique terdiri dari } 288 \text { halaman, berisi tahap-tahap } \\
\text { pengajaran, latihan dan kunci jawaban. }\end{array}$ \\
\hline
\end{tabular}


Para responden selanjutnya menyampaikan rekomendasi sebagai berikut: (1) Pengajar harus terus mengikuti perkembangan kebutuhan dari mahasiswa dan terus menerus melakukan inovasi dalam penyampaian materi sehingga tidak selalu terpaku pada buku ajar. (2) Dalam menyampaikan materi terutama gramatika, hendaknya disertai pembahasan langsung terhadap latihan-latihan yang terdapat di bagian belakang buku ajar. (3) Pembahasan mengenai buku ajar sebaiknya melibatkan pemangku kepentingan (stake holder) termasuk pengguna lulusan.

Dari hasil pengisian angket bagian pertama ini, sebagian besar responden dosen menyatakan bahwa dibandingkan buku ajar yang digunakan sebelumnya, Cosmopolite 1 lebih tematis, terstruktur, detail, dan teratur. Mahasiswa bersikap antusias dalam menggunakan buku ini sehingga mendapatkan nilai yang baik. Tidak semua perlengkapan buku ajar digunakan dalam kelas karena eksplorasi terhadap CD misalnya, dapat dilakukan oleh mahasiswa saat berada di rumah. Seluruh responden dosen bersepakat bahwa mereka masih dapat melengkapi pengajaran Bahasa Perancis Dasar dengan buku dan media lain sebagai variasi. Mereka juga menyetujui bahwa ada keterkaitan antara kualitas buku ajar dengan ketercapaian proses pembelajaran, dan menyatakan bahwa buku tersebut memenuhi asas keterbacaan. Seperti hasil yang diperoleh dalam penelitian Jamilah et al. (2020, hal. 22) dijelaskan bahwa penggunaan produk bahan ajar interaktif sebaiknya pendidik menjelaskan kembali materi ataupun soal-soal latihan yang terdapat di dalamnya.

Berdasarkan kuesioner pakar tentang materi dari buku ajar Cosmopolite 1, menurut seluruh responden dosen (100\%), buku tersebut mencapai tingkat kesesuaian "tinggi" pada kriteria (8), dan (10). Sebagian besar responden $(66,7 \%)$ juga menyatakan tingkat kesesuaian "tinggi' pada kriteria (1), (2), (3), (4), (7), dan (9). Tingkat kesesuaian "sedang" dicapai melalui kriteria (5) dan (6). Hal ini berarti bahwa seluruh responden dosen meyakini materi di dalam buku ajar Cosmopolite 1 tidak mengandung kesalahan penyampaian informasi dan telah sesuai dengan situasi sosial budaya pembelajar di Indonesia. Sebagian besar responden juga mengafirmasi bahwa materi dalam Cosmopolite 1 sesuai dengan perkembangan pemikiran dalam bidang ilmu bahasa Perancis, dapat menjelaskan konsep kebahasaan dengan tuntas, menyajikan metode yang konsisten, tersusun secara koheren dan logis, terdapat tes yang relevan, dan dilengkapi ilustrasi yang membantu pemahaman. Namun demikian, tingkat kesulitan buku ajar ini dianggap tidak cukup memenuhi kesesuaian dengan jenjang program (dianggap relatif mudah) dan tidak cukup dalam membahas teori kebahasaan. Hal inilah yang menyebabkan responden dosen harus melengkapi materi dari buku dan media lain yang relevan.

Untuk mendapatkan gambaran komprehensif dari evaluasi terhadap penggunaan buku ajar Cosmopolite 1 dalam pembelajaran Bahasa Perancis, selanjutnya pembahasan dilakukan dari sudut pandang pembelajar.

\section{Evaluasi Penggunaan Buku Ajar Cosmopolite 1 dalam Pembelajaran Bahasa Perancis menurut Mahasiswa}

Tiga puluh mahasiswa yang menjadi responden dalam penelitian ini berada di semester II, dan mengisi angket yang terdiri dari 10 pertanyaan serta bagian saran/rekomendasi. Sebanyak $96,7 \%$ responden menyatakan selalu membawa buku ajar Cosmopolite 1 karena diwajibkan dosen (1). Sebagian besar dari mereka (90\%) merasa nyaman menggunakan buku ajar tersebut karena ilustrasinya menarik, tidak 
terlalu berat, dan di dalamnya terdapat banyak latihan (2). Sebanyak $86,7 \%$ mengakui bahwa buku ini pun mudah dibaca dan dipahami (3). Dari seluruh responden, sebanyak $73,3 \%$ responden menyatakan tidak ada bagian dari Cosmopolite 1 yang sulit dimengerti. Yang lainnya, 13,3\% menganggap bagian Projets 'tugas kelompok', 10\% menganggap Focus Langue 'tata bahasa', dan 3,33\% menunjuk Sons $d u$ français 'latihan fonetik' sebagai bagian yang sulit dari buku tersebut (4). Sebaliknya, 63,3\% responden menyatakan paling menyukai bagian Culture 'budaya', 20\% Projets, 10\% Focus langue, dan 6,67\% memilih Sons du français (5).

Delapan puluh persen responden mendapatkan nilai yang baik untuk mata kuliah Bahasa Perancis Dasar (nilai A atau B) setelah menggunakan buku ajar Cosmopolite 1 (6). Sebagian besar responden atau 93,3\% menyatakan sering membaca dan mempelajari buku ajar tersebut di luar jam belajar dan di luar kampus, dengan alasan ada tugas atau karena ingin belajar sendiri (7). Sepengetahuan $90 \%$ responden mahasiswa, dosen pengampu selalu menggunakan Cosmopolite 1 untuk pengajaran, dan kadang-kadang saja memberi tambahan dari referensi lain. Tambahan materi yang dimaksud di antaranya latihan tata bahasa, daftar kosa kata, dan video tentang kebudayaan Perancis yang relevan dengan materi buku ajar (8). Sekitar 86,7\% responden menyatakan bahwa Cosmopolite 1 membuat mereka ingin belajar lebih jauh tentang Bahasa Perancis (9). Sebanyak 73,3\% responden juga menilai pergerakan pengajaran dalam buku ajar tersebut sudah cukup progresif (10).

Selain menjawab pertanyaan yang diajukan dalam angket, empat belas mahasiswa atau 46,7\% responden memberikan saran dan rekomendasi terkait pembelajaran Bahasa Perancis yang menggunakan buku ajar Cosmopolite 1. Menurut responden mahasiswa, selain menggunakan buku ajar, dosen sebaiknya memang memberikan materi dari sumber lain agar ada variasi. Mereka juga menyarankan agar dosen tidak terlalu banyak memberikan tugas tertulis dari buku, dan sebaliknya memberikan evaluasi berupa tes lisan untuk memeriksa pemahaman mahasiswa. Responden juga berpendapat bahwa materi double page ‘dua halaman' untuk durasi kuliah 100 menit tidak selalu memadai. Mereka mengharapkan ada sesi belajar di luar kelas dengan penutur asli Bahasa Perancis, meskipun biasanya dosen asing memang tidak mengajar di semester awal (1-2). Responden berharap dosen dapat menggunakan Bahasa Perancis meskipun mengajar di semester 1-2 supaya mahasiswa terbiasa mendengar pelafalan yang benar.

Evaluasi penggunaan Cosmopolite 1 dari sudut pandang mahasiswa sebagai pembelajar ini secara kuantitatif menunjukkan kecenderungan nilai positif bagi buku ajar tersebut. Kualitas yang dilekatkan para responden terlihat di antaranya dari pemilihan kata sifat seperti: nyaman, mudah dipahami, progresif, [belajar secara] mandiri, menarik, mudah dibaca.

\section{Pengembangan Penggunaan Buku Ajar Cosmopolite 1 untuk Meningkatkan Kualitas Pembelajaran Bahasa Perancis}

Berdasarkan kajian Arismendi (2018), sistematisasi buku ajar Cosmopolite 1 ini terdiri dari delapan bab yang masing-masingnya berisi enam pelajaran. Setiap bab dibahas dalam double-page 'per dua halaman', mulai dari elemen budaya, proyek, dan DELF (tes kemampuan bahasa Perancis yang diakui secara internasional). Setiap bab dimulai dengan double-page 'perdua halaman' yang bertujuan untuk mengeksplorasi dan mengembangkan pengetahuan awal siswa tentang tema yang akan dibahas. Sejak halaman-halaman pertama ini, sudah disiapkan rencana proyek 
yang akan dilakukan oleh para siswa baik secara individual maupun kelompok. Proyek tersebut disesuaikan dengan tingkat kemampuan mereka. Setiap pelajaran akan disertai tugas, yang pada umumnya dilakukan secara kolaboratif dan berujung pada presentasi lisan dan tulisan. Untuk itu disediakan sejumlah dokumen pendukung. Pembahasan tentang tata bahasa, sistem fonetik, dan kosa kata diintegrasikan dengan fokus bahasa dan bunyi dalam bahasa Perancis.

Menurut modul yang disusun Departemen Pendidikan Nasional (2003) yang dikutip Hernawan (Hernawan et al., 2010), bahan ajar harus memiliki beberapa karakteristik, yaitu: selfinstructional, selfcontained, stand alone, adaptive, dan user friendly.

Pertama, self instructional yang berarti bahan ajar harus dapat mendorong siswa membelajarkan dirinya sendiri. Untuk memenuhi kriteria ini, maka di dalam bahan ajar harus dirumuskan tujuan pembelajaran yang jelas, baik tujuan akhir maupun tujuan antara. Selain itu dengan bahan ajar, siswa akan belajar secara tuntas karena materi dikemas dalam unit-unit atau aktivitas yang spesifik. Cosmopolite 1 dapat memenuhi kriteria selfinstructional karena memuat alur pembelajaran yang jelas yang ditempatkan di bagian awal buku. Pada setiap bab, terlihat adanya tujuan yang dirumuskan dengan jelas, terdapat materi pembelajaran yang dikemas dalam unit yang lebih kecil untuk mempermudah pembelajaran. Selain materi, juga ada alur instruksi yang jelas pada soal latihan. Buku ini bersifat kontekstual, menggunakan bahasa yang sederhana dan komunikatif, serta menyediakan rangkuman materi pembelajaran di bagian akhir yang terdiri dari Précis de phonétique (hal. 202-207), Précis de grammaire (hal. 208-217), dan Précis de conjugaison (hal. 218-219).

Kedua, self contained yang berarti seluruh materi pelajaran dari satu unit kompetensi atau subkompetensi yang dipelajari terdapat di dalam satu bahan ajar secara utuh. Dengan demikian, sebuah bahan ajar memuat seluruh bagian dalam satu buku utuh untuk memudahkan pembaca mempelajari materi tersebut. Dalam satu unit kompetensi, terdapat elemen-elemen yang keberadaannya konsisten, seperti dalam 1 Dossier 'bab' dalam Cosmopolite 1. Dalam tabel 2 berikut ini terlihat adanya pembagian yang jelas meliputi tipe wacana, kemampuan yang diharapkan tercapai, tata bahasa, kosa kata, dan fonetik.

Ketiga, stand alone, yang berarti bahan ajar tidak bergantung pada bahan ajar lain atau tidak harus digunakan bersama-sama dengan bahan ajar lain. Cosmopolite 1 sebenarnya telah lengkap sebagai sebuah buku ajar yang dilengkapi media lainnya sebagai berikut. Penambahan materi dari buku lain sebenarnya tidak terlalu dibutuhkan, namun dapat dilakukan bila memang diperlukan adanya variasi terutama yang berkaitan dengan tata bahasa, kosa kata, dan kebudayaan Perancis seperti yang terungkap pada bagian evaluasi oleh dosen pengampu dan mahasiswa.

Keempat, adaptive, yang berarti bahan ajar harus memiliki daya adaptif yang tinggi terhadap perkembangan ilmu dan teknologi. Materi yang terkandung di dalam bahan ajar itu harus dapat menambah pengetahuan pembaca terkait perkembangan zaman, khususnya yang berkaitan dengan ilmu dan teknologi. Buku ajar Cosmopolite 1 dinilai mengikuti kemajuan teknologi meskipun tema-tema dasar yang dipelajari adalah tentang kehidupan sehari-hari. Keluwesan atau fleksibilitas buku ajar ini merupakan nilai lebih karena penggunaan Cosmopolite 1 dapat memanfaatkan teknologi multimedia secara aktif. Mahasiswa dan dosen dapat melakukan eksplorasi sendiri di mana saja. Kriteria ini sesuai dengan karakter mahasiswa masa kini yang sangat bergantung pada teknologi terutama media sosial. Dengan akses pada Parcours 
digital 'jalur digital', disediakan 300 buah aktivitas yang bersifat otokorektif, proyek individual, dan petunjuk bagi pengajar untuk menempatkan kelasnya secara hibrid.

Kelima, user friendly, yang berarti setiap instruksi dan paparan informasi yang tampil harus bersifat membantu pemakainya, memudahkan dalam merespons dan mengakses materi sesuai dengan kebutuhan. Buku Cosmopolite 1 secara spesifik membedakan instruksi bagi penggunanya, yaitu pengajar dan pembelajar, sebagaimana dibedakan manuel 'buku pegangan' dan cahier d'exercice 'buku latihan' bagi mahasiswa dan guide pédagogique 'panduan pedagogis' bagi dosen. Cosmopolite 1 telah memberikan pengantar yang jelas pada bagian Avant-propos 'pengantar' bahwa publik sasaran buku ini adalah grand adolescents et adultes 'remaja dan dewasa' yang berarti dapat digunakan dalam konteks pembelajaran bahasa Perancis khususnya di universitas. Karena Cosmopolite 1 ditujukan pada pembelajar pemula bahasa Perancis, maka teks-teks yang disajikan masih bersifat sederhana dan merupakan teks deskriptif dan naratif.

Pendekatan yang digunakan adalah dengan perspektif actionnelle 'aksionel' berbasis proyek, berupa proyek kelas dan proyek individual yang terbuka. Contoh proyek kelas pada bab 8 adalah mengorganisir sebuah pesta untuk merayakan hasil kelulusan ujian bahasa Prancis, sedangkan proyek individual misalnya membuat presentasi audio dan video dari hasil pembelajaran bahasa Prancis dan memublikasikannya pada situs berbagi. Untuk merealisasikan kedua proyek, para pembelajar harus mengelola savoirs 'pengetahuan', savoir-faire 'pengetahuan bertindak', savoir-agir 'pengetahuan bereaksi', compétences générales 'kemampuan umum', langagières 'berbahasa' et culturelles 'budaya' mereka.

\section{PENUTUP}

Berdasarkan hasil analisis data, dapat disimpulkan bahwa evaluasi yang telah dilakukan oleh responden dosen dan mahasiswa terhadap buku ajar Cosmopolite 1 menunjukkan nilai yang positif, di antaranya relevan dengan kebutuhan pembelajaran yaitu mencapai kompetensi berbahasa Perancis tingkat dasar. Materi pembelajaran jelas, menarik, dan mudah dipahami sehingga menarik minat mahasiswa untuk belajar secara mandiri. Secara keseluruhan, komponen dari buku ajar juga dinilai baik. Namun demikian, ada kelemahan yang terungkap yaitu masih diperlukannya tambahan materi dari buku dan media yang lain sehingga kriteria stand alone, yang seharusnya dimiliki oleh sebuah buku ajar Cosmopolite 1 menjadi diragukan. Agar sebuah buku ajar dapat digunakan dengan baik, perlu dilakukan pengenalan baik oleh siswa maupun guru terhadap buku yang akan digunakannya. Mutu dari sebuah buku ajar sebenarnya tergantung dari efektif tidaknya saat digunakan dalam proses pembelajaran, semakin banyak kebutuhan yang terlayani, maka akan lebih baik (Suryaman, 2015). Buku ajar yang baik juga memberi kesempatan pada pembelajar untuk belajar sesuai dengan kecepatannya sendiri, untuk melakukan pendalaman, untuk membuat catatan hal-hal yang penting, misalnya dengan memanfaatkan setiap unsur yang tersaji di dalam buku tersebut secara optimal.

\section{DAFTAR PUSTAKA}

Adawiyah, A. Al. (2016). Penyajian Buku Kumpulan Materi Parlez Français sebagai Strategi Pengenalan Dasar-dasar Pembelajaran Bahasa Perancis. Simposium 
Internasional Bahasa, Sastra, Dan Budaya, 341-354. Diambil dari http://journal.fib.uho.ac.id/index.php/simposiumbahasa/article/view/321

Arismendi, F. (2018). Nathalie Hirschsprung et Tony Tricot, Cosmopolite : méthode de français. Lidil, 57. https://doi.org/10.4000/lidil.4842

Cahyani, I., \& Hadianto, D. (2018). Rekonstruksionisme: Metode Komunikatif dalam Pemerolehan dan Pembelajaran Bahasa untuk Mengembangkan Kemampuan Berbahasa. Jurnal Kata, 2(1), 118-123. https://doi.org/10.22216/jk.v2i1.3065

Dhewi, R. M., \& Hadiwidjaja, R. D. (2014). Analisis Kritikal Bahan Ajar Pengantar Akuntansi (EKMA4115) Menggunakan Evaluasi Formatif. Diambil dari http://repository.ut.ac.id/5522/1/2014_21.pdf

Fatin, I. (2017). Keterbacaan Buku Teks Bahasa Indonesia Kelas X Kurikulum 2013 Edisi Revisi 2016 dengan Formula FRY. Belajar Bahasa, 2(1), 21-33. https://doi.org/10.32528/bb.v2i1.643

Halijah, S., Susilo, \& Mulawarman, W. G. (2020). Pengembangan Bahan Ajar Menulis Deskriptif Menggunakan Model Kooperatif Round Table dengan Media Audio pada Siswa Kelas X SMA. Diglosia: Jurnal Kajian Bahasa, Sastra, dan Pengajarannya, 3(2), 115-124. https://doi.org/10.30872/diglosia.v3i2.25

Hernawan, A. H., Permasih, \& Dewi, L. (2010). Pengembangan Bahan Ajar. Diambil dari

http://file.upi.edu/Direktori/FIP/JUR._KURIKULUM_DAN_TEK._PEN DIDIKAN/194601291981012-

PERMASIH/PENGEMBANGAN_BAHAN_AJAR.pdf

Hijriah, T. F. (2017). Evaluasi Buku Ajar Bahasa Arab: Telaah terhadap Instrumen Penilaian Badan Standar Nasional Pendidikan (BSNP) dan Rusydi Ahmad Thu'aimah. Diambil dari http://eprints.ums.ac.id/55099/12/PUBLIKASI IL.pdf

Hirschprung, N., \& Tricot, A. (2017). Cosmopolite 1: méthode de français. Hachette FLE.

Intan, T., Rijati, S., \& Hasanah, F. (2020). Ideologi Gender dalam Buku Ajar Bahasa Perancis Cosmopolite 1. Jurnal Pendidikan Bahasa dan Sastra, 19(1), 37-50. https://doi.org/10.17509/bs_jpbsp.v19i1.20757

Jamilah, N., Mulawarman, W. G., \& Hudiyono, Y. (2020). Pengembangan Bahan Ajar Interaktif 'POST' dalam Pembelajaran Apresiasi Puisi untuk Siswa Kelas X SMA. Diglosia: Jurnal Kajian Bahasa, Sastra, dan Pengajarannya, 3(1), 14-23. https://doi.org/10.30872/diglosia.v3i1.28

Mahriyuni. (2016). Pembelajaran Bahasa Perancis Berbasis CECR dalam Konteks Plurilinguisme bagi Guru dan Siswa SMA. Bahas, $X X X V(69)$. Diambil dari https://jurnal.unimed.ac.id/2012/index.php/bahas/article/view/2394

Majid. (2007). Perencanaan Pembelajaran Mengembangkan Standar Kompetensi Guru. Bandung: PT. Remaja Rosdakarya.

Mayasari, R., Sapri, J., \& Turdjai, T. (2019). Pengembangan Bahan Ajar Bahasa Jerman Berbasis Komik untuk Meningkatkan Kosakata dan Keterampilan Berbicara (Studi Pengembangan di SMAN 2 Kota Bengkulu). Diadik: Jurnal Ilmiah Teknologi Pendidikan, 8(1), 88-98. Diambil dari https://ejournal.unib.ac.id/index.php/diadik/article/view/7230

Mulyadi, Y. (2014). Penggunaan textes médiatiques pada laman www.jde.fr dalam rangka pengembangan bahan ajar perkuliahan Compréhension Ecrite II. 
Seminar Internasional Bahasa Perancis.

Mutiarsih, Y. (2005). Efektivitas Penggunaan Buku Teks Campus dalam Pembelajaran Struktur Bahasa Perancis. Bandung.

Oktari, D. A. (2013). Analisis Materi Pembelajaran Bahasa Perancis pada Buku Complete French Volume I. Universitas Pendidikan Indonesia.

Oktarini, E., \& Gafur, A. (2014). Evaluasi Formatif pada Video Pembelajaran Majoe Djaya Produksi Eduartion. Jurnal Inovasi Teknologi Pendidikan, 1(1), 40-48. https://doi.org/10.21831/tp.v1i1.2458

Pujiati. (2012). Pengembangan Bahan Ajar Praktikum Pengantar Akuntansi Untuk Mahasiswa Jurusan Akuntansi. Jurnal Ekonomi dan Pendidikan, 4(2). https://doi.org/10.21831/jep.v4i2.609

Rahman, Sahlan, \& Badara, A. (2020). Evaluasi Bahan Ajar Bahasa dan Sastra Indonesia Kelas VIII di SMP Negeri 1 Asera Konawe Utara. Jurnal Pendidikan Bahasa, 9(1), 1-11. Diambil dari http://ojs.uho.ac.id/index.php/JPB

Sari, K. P. (2018). Evaluasi Bahan Ajar Bahasa Prancis Le Mag sebagai Bahan Pembelajaran Mandiri Siswa Sekolah Menengah Atas. Jurnal Inovasi Teknologi Pendidikan, 4(2), 214-226. https://doi.org/10.21831/jitp.v4i2.17155

Shafwatun, N. S. (2016). Jenis Bahasa Argot dalam Buku Teks Pelajaran Bahasa Prancis Alter Ego 3. Universitas Negeri Jakarta.

Sumiyati, S., \& Surjono, H. D. (2014). Pengembangan Multimedia Pembelajaran untuk Meningkatkan Penguasaan Kala Lampau Bahasa Prancis Mahasiswa. Jurnal Inovasi Teknologi Pendidikan, 1(2), 199-212. https://doi.org/10.21831/tp.v1i2.2530

Suryaman, M. (2015). Dimensi-Dimensi Kontekstual di dalam Penulisan Buku Teks Pelajaran Bahasa Indonesia. Diksi, 13(2), 165-178. https://doi.org/10.21831/diksi.v13i2.6456

Tarigan, H. G., \& Tarigan, D. (1986). Telaah Buku Teks Bahasa Indonesia. Bandung: Angkasa.

Tim Hachette FLE. (2016). Cosmopolite: La nouvelle méthode de français pour grands adolescents et adultes.

Utami, N. N. (2016). Variasi Bahasa Prancis Anak Muda dalam Pembelajaran Bahasa Prancis. Yogyakarta. Diambil dari http://staffnew.uny.ac.id/upload/131764500/penelitian/PEMAKAIAN+++ BAHASA++REMAJA+-+Copy.pdf 